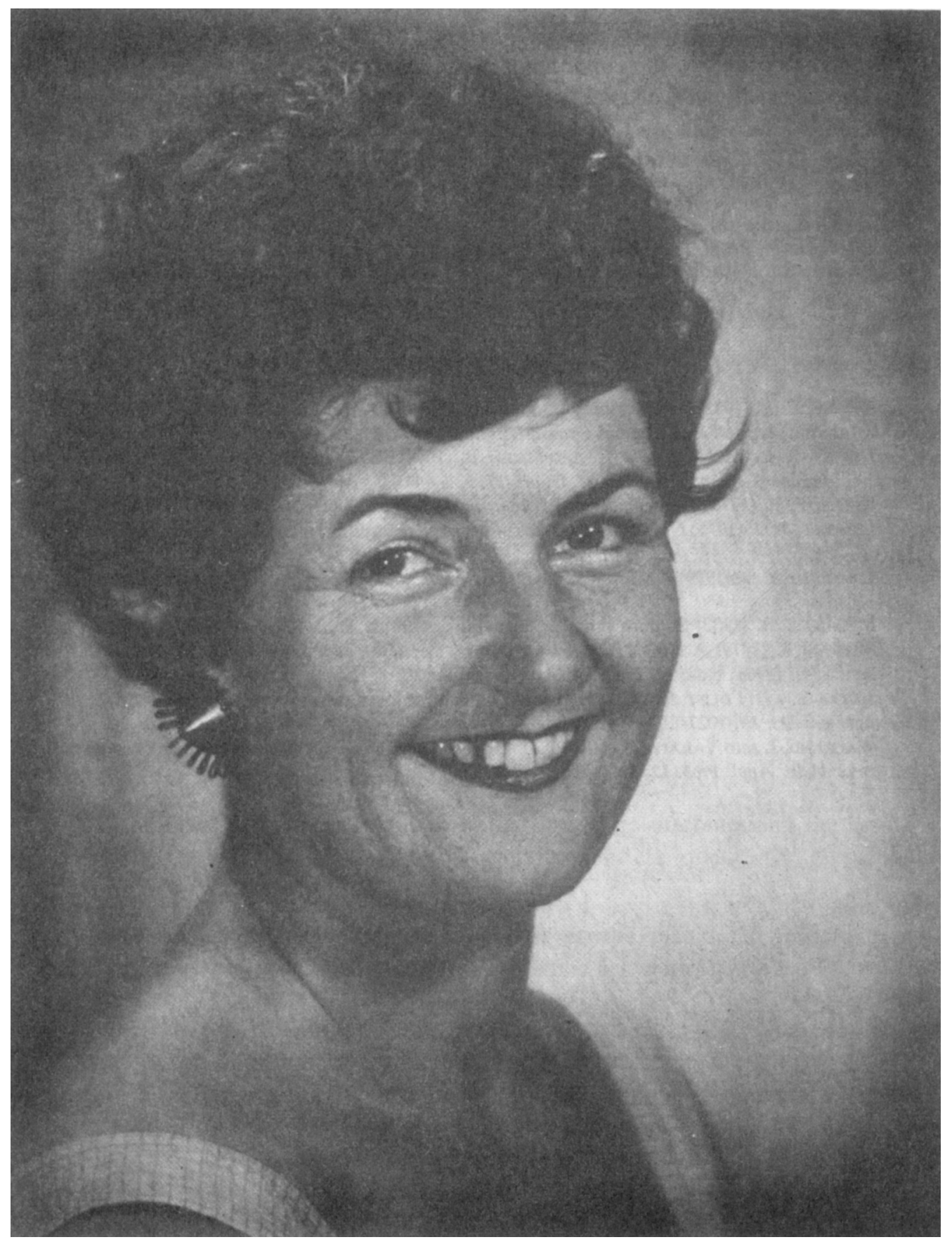

Norma McArthur in 1957, when she was Census Commissioner, Fiji. 


\section{Obituary: DR NORMA RUTH MCARTHUR}

Norma McArthur, one of the four founding trustees of the Applied Probability Trust, died at her home in Canberra, Australia, on 17 January 1984. She had fought a long battle with cancer, exhibiting great resilience, clear-sightedness and courage to the last. When we took leave of each other in Canberra in August 1983, she was making plans for our next meeting in July 1984.

Norma McArthur was born on 12 July 1921 in the small Australian country town of Ararat, in Victoria, where her father was a timber merchant and builder. She was a talented student, who after leaving school, entered the University of Melbourne where she graduated B.A. in 1941 with a major in Mathematics. She retained a strong interest in the University of Melbourne throughout her life, and spoke affectionately of her colleagues there, and of her long association with its Women's College.

During the Second World War she carried out statistical work in wartime administration and industry, and after 1945 worked for a while with Sir Macfarlane Burnet in the Department of Experimental Medicine at the University of Melbourne. An early paper on influenza epidemics published in 1947 with Burnet and Pickles [1] dates from this period. In 1947 she joined the Department of Eugenics, Biometry and Genetics, University College London (UCL) as a graduate student, and was awarded her Ph.D. in Biological Statistics from the University of London in 1949.

Her professors at UCL were J. B. S. Haldane and L. S. Penrose; she was primarily a student of Penrose and her thesis and early research were concerned with the genetics of blood groups and twinning. A paper published with Penrose [2] in 1950, for example, deals with the world frequencies of blood group genes. In 1949, she was appointed Assistant Lecturer in Demography in the same department; she held this post for three years. It was during this period in Britain that she first visited Italy, a country of which she spoke often, with enjoyment, and whose language and people she grew to love.

She returned to Australia in 1952 to a Research Fellowship in the Department of Demography of the newly created Australian National University (ANU). It was there that we first met in 1953, when I was a graduate student in the ANU Department of Statistics. She continued to serve the Department of Demography as a Fellow from 1958-1960, a Senior Fellow from 1960 to 1963 and a Professorial Fellow from 1963 to 1970 , a total of 18 years. During this time, her 
research turned from the genetic studies of twinning summarised in her monograph Genetics of Twinning [3], to population studies both statistical and social, more particularly of the South Pacific Islands.

It was during 1963 that we first discussed the possibility of founding the Applied Probability Trust (APT). Evidence had been mounting that a Journal of Applied Probability was likely to be viable, and an editorial board had tentatively agreed to serve, but finance was proving a difficulty. Norma's mathematical and statistical background enabled her to appreciate the aims and ideas of such a journal, and when I explained the position to her, she spontaneously offered to provide some of the initial finance to help launch the APT. Thus, together with Professor E. J. Hannan, Sir Edward Collingwood for the London Mathematical Society, and me, she became one of the four founding trustees of the APT. Her broad scholarly perspective, her business sense, and her understanding of human affairs made her a valuable colleague on the APT Board of Trustees.

Norma McArthur was not only a highly regarded scholar, but also an excellent organizer and administrator. During 1956-8, she served as Census Commissioner in Fiji, where the accompanying photograph was taken. She later took part in censuses of the British Solomon Islands Protectorate in 1959, the Gilbert and Ellice Islands Colony in 1963 and the Condominium of the New Hebrides in 1967. Her work on these censuses is outlined in the Reports [4], [5], [6], [7]. She would occasionally recount some interesting anecdotes on the difficulties of carrying out systematic censuses on these islands.

Her wide experience of population statistics was to bear fruit in two books. The earlier of these was Introducing Population Statistics [8] published in 1961, and translated into French in 1964, while the later Island Populations of the Pacific [9] which appeared in 1967, was possibly her major work. This book outlined the rise and fall of populations in a number of Pacific islands on the basis of data provided by explorers, missionaries and government officials; it challenged the theory of severe population decline as a result of contact with Europeans.

Her demographic career officially came to an end in 1970, when she decided to resign her Professorial Fellowship in the ANU Department of Demography. Characteristically, she also decided it was time to make a change in her area of interest. Her book on Island Populations of the Pacific had relied mainly on European records, and she felt the need to match these with archaeological data which might reveal other aspects of island population trends. She became a graduate student in the Department of Prehistory at the ANU in 1970 and was awarded her second Ph.D. in 1974. Her archaeological fieldwork involved her spending several months on the island of Aneityum in the New Hebrides (Southern Vanuatu); her living conditions there were extremely primitive and involved her in considerable physical hardship. To prepare herself for her task, 
she walked up Black Mountain, a tall hill near the ANU in Canberra, every day for an extended period, in order to harden herself physically.

Soon after obtaining her Ph.D. she was appointed Visiting Fellow in the ANU Department of Prehistory for three months, and in 1975 Senior Research Fellow in the ANU Department of Pacific and South East Asian History, a post which she held until 1980 . Her work was concerned mainly with the archaeology, history and statistics of populations in the South Pacific, among them those in New Caledonia and Hawaii. She was also interested in the statistics of Kuru [10], the dreaded viral disease of the New Guinea Highlands. In the late 1970s, she consulted me on the problem of survival of groups of individuals who had migrated to Pacific Islands in small numbers by canoe. Why had some island populations been able to survive while others had become extinct? And could one construct suitable probabilistic models to explain this phenomenon? On my advice, she began to work with I. W. Saunders and R. L. Tweedie of the CSIRO Division of Mathematics and Statistics on small population models, and together they carried out some simulation studies [11].

Norma McArthur was a woman of strong character, with pronounced feelings of social responsibility. She served as representative of the non-professorial staff of the Institute of Advanced Studies on the ANU Council between 1975 and 1977. She was forthright and sometimes uncomfortably honest, but her integrity was never in doubt. She maintained her principles, even when they cut across her self-interest. She was a widely read woman, a lover of classical music, and a very human individual with a wide circle of friends throughout the world. During 1982 and 1983, when it became obvious that her health would not improve, she continued to read, to maintain her interest in her current work, and to discuss the future of the ANU, of Australia and of the world with her friends.

Last July 1983, her fellow trustees on the APT decided to honour her by donating a Trust Prize named after her to the Department of Statistics in the University of Melbourne. I had mentioned this to her privately in July, and when arrangements were completed in August 1983, Miss Mavis Hitchcock, Executive Editor of the Trust, wrote to her formally, asking if she had any particular views on the use of the Prize. Modest to a fault, Norma wrote back on 4 September 1983:

'Yes, Joe did mention the prize, and far be it from me to have any special ideas about it. I am enormously flattered.'

The Trust owes Norma McArthur a debt greater than it can ever repay. Her fellow trustees will greatly miss her broad experience, her honest counsel, her good humour, her strength of character, and her great humanity.

University of Kentucky

J. GANI

April 1984 


\section{Selected Publications of Norma R. McArthur}

[1] Epidemic respiratory infection in a rural population with special reference to the influenza $A$ epidemics of 1933, 1936-7 and 1943-4. Journal of Hygiene 45 (1947), 469-473 (with W. N. Pickles and F. M. Burnet).

[2] World frequencies of the O, A, and B blood group genes. Annals of Eugenics 15 (1950), 302-305 (with L. S. Penrose).

[3] Genetics of Twinning: A Critical Summary of the Literature. Australian National University Social Science Monograph, No. 1, Canberra (1953).

[4] Colony of Fiji, Report on the Census of the Population, 1956. Legislative Council, Fiji, Council Paper No. 1 (1958).

[5] Report on the Population Census of 1959. Western Pacific High Commission, British Solomon Islands Protectorate, Honiara (1961).

[6] Report on the Census of the Population of the Gilbert and Ellice Islands Colony, 1963. Government Printer, Fiji (1964) (with J. B. McCaig).

[7] Condominium of the New Hebrides, Report on the First Census of the Population, 1967. N. S. W. Govt. Printer, Sydney (1968) (with J. F. Yaxley).

[8] Introducing Population Statistics. Oxford University Press, Melbourne (1961) (French edition, Dunod, Paris, 1964).

[9] Island Populations of the Pacific. ANU Press, Canberra (1967).

[10] Cross-currents: the statistics of Kuru. Human Biology in Oceania 1 (1972), 289-298.

[11] Small population isolates: a micro-simulation study. J. Polynesian Soc. 85 (1976), 307-326 (with I. W. Saunders and R. L. Tweedie). 